\title{
Effect of Four Host Plants of the Two Spotted Spider Mite Tetranychus urticae on the Consumption Rates and Reproductive Biology of the Predator Blaptostethus pallescens Poppius (Hemiptera: Anthocoridae)
}

\author{
Nesrin A. El-Basha \\ Department of Biological Control, Plant Protection Research Institute, Agricultural Research Center, Giza, Egypt
}

\section{Received: $7 / 3 / 2016$}

\begin{abstract}
Blaptostethus pallescens Poppius (Hemiptera: Anthocoridae) is a potential predator on mites and other insects in Maize, Mango and grain warehouses in Egypt. The indirect effect of four vegetable crops; bean (Phaseolus vulgaris), pepper (Capsicum annuum), eggplant (Solanum melongena) and cucumber (Cucumis sativus) as host-plants of the two spotted spider mite (TSSM) Tetranychus urticae Koch on the consumption rate and reproductive biology were studied at $30 \pm 1{ }^{\circ} \mathrm{C}$ and $60 \pm 10 \%$ R.H. The obtained results revealed that the type of plant had a significant effect on the daily and overall prey consumption of all the nymphal instars and total developmental nymphal periods. The total predation rates of all nymphal instars of $B$. pallescens were higher with bean leaf plant (552.4 mites) than that of pepper, eggplant and cucumber leaf plants (520.5, 451.8 and 349.2 mites, respectively). The major portion of mortality during the nymphal stage occurred during the first instar in all tested host plants and the higher mortality was recorded when TSSM fed on mites fed cucumber plant, and the lower one was for mites fed on bean plant. The total number of consumed $T$. urticae nymphs by $B$. pallescens adult females was significantly different among the four host plants; being higher in bean plant leaves (301.9 mites) and lower on cucumber plant leaves (152.4 mites). Also, the total number of consumed $T$. urticae nymphs by B. pallescens adult males was significantly different among the four host plants; being higher in bean plant leaves (158.8 mites) and lower on cucumber plant leaves (105.3 mites). Significant differences in adult longevity among the different host plants were observed, the shortest lifetime for females was 17.7 days on cucumber, while the longest lifetime (22.3 days) was recorded with bean. The oviposition period was shortest on cucumber (10.5 days) and longest on bean (17.7days). Meanwhile, the greatest total lifetime fecundity (70.0 eggs/ female) was observed with bean plant, which was significantly higher than on cucumber plant (22.9 eggs/female). The success of $B$. pallescens as a biological control agent of TSSM seems to be strongly affected by the host plants on which the TSSM were fed on.
\end{abstract}

Keywords: Blaptostethus pallescens, Tetranychus urticae, host plants, biological control, predation, reproductive biology

\section{INTRODUCTION}

The two-spotted spider mite (TSSM), Tetranychus urticae Koch (Acari: Tetranychidae) is one of the most important pests in Egypt and around the world in various vegetable crops grown in greenhouses and open fields, especially Solanaceae, Cucurbitaceae and Leguminosae (Zaher, 1986; Ahmed, 1988; Zhang, 2003; Singh et al., 2004; Sarwar et al. 2011; Abd-Elhady and Heikal, 2011). Biological control is a profitable alternative to the use of chemical pesticides in the agroecosystems (Lester et al., 2000).

Generalist predatory insects attack a diverse spectrum of prey species (Eubanks and Denno, 2000). Blaptostethus pallescens Popp. (Hemiptera: Anthocoridae) is a generalist predator that preys upon eggs and immature stages of various arthropods, or small soft-bodied adult arthropods, including numerous important agricultural pest species. B. pallescens has been assessed as a potential predator of pests in Maize, Mango and grain warehouses in Egypt where mite pests are common (Tawfik and El Husseini, 1971). It is abundant on maize after ears formation and generally attacks eggs and young larvae of lepidopteran pests, including Chilo Agamemnon Bleszynski, Ostrinia nubilalis (Hb.), Spodoptera littoralis (Boisd.), larvae of Pyroderces simplex Wlsm. and Cryptoblabes gnidiella (Mill.). It is also known to prey on certain sucking insect pests, such as Rhopalosiphum maidis (Fitch) and Tetranychus spp. (Tawfik and El-Husseini, 1971; Tawfik et al., 1974). An attempt was made to evaluate the efficacy of $B$. pallescens as a predator of $T$. urticae

\footnotetext{
*Corresponding author: nesrinelbasha@hotmail.com
}

in the laboratory and net house (Ballal et al., 2009). Also, Ballal et al., (2012) found that B. pallescens could feed on two species of mealybugs, Phenacoccus solenopsis and Paracoccus marginatus. Abd-Elgayed and Hussein, (2014) reared B. pallescens on larvae of Pyroderces simplex, Cryptoblabes gnidiella, Gymnoscelis pumilata on maize. Studies of some basic biological characteristics; the effects of temperature on the development and reproduction of $B$. pallescens, the impact of mating on adult longevity under various temperatures, as well as the influence of non-prey food on adult longevity could be useful for developing massrearing programs for anthocorid biological control agent (Sobhy et al., 2014). B. pallescens releases against $T$. urticae revealed that $B$. pallescens is a promising candidate to control TSSM (Ballal et al., 2009).

As B. pallescens oviposits into the host plant tissues. Little is known about the plant-predator interactions, which are crucial for planning an integrated management combining biological control. The efficiency of the predators and preys can be affected by the texture and morphology of the surface that they search (Grevstad et al., 1992), which can be monitored by their consumption and oviposition rates and influence their effectiveness as biological control agent. The morphology of plant surfaces may influence herbivore and natural enemies' interactions (Roda et al., 2001; Kheradpir et al., 2013). Host plants can influence the natural enemies of insect pests in two ways, either indirectly or directly (Price et al., 1980). Indirect plant effects involve the nutritional state of the prey altered

Volume 5 (1): 23-29 
prey behavior or reduced prey population growth. Direct plant effects on natural enemies include both the physical and chemical characteristics of the host plant. However, there is no information available on the influence of feeding consumption and reproductive biology of $B$. pallescens by different host-plants infested with TSSM.

Therefore, The objective of this study is to investigate the indirect effect of four vegetable crops namely bean, Phaseolus vulgaris (Leguminosae); pepper, Capsicum annuum (Solanaceae); eggplant, Solanum melongena (Solanaceae) and cucumber, Cucumis sativus (Cucurbitaceae) as host-plants for the TSSM on the consumption rates and reproductive biology of $B$. pallescens under laboratory conditions.

\section{Mite colony}

\section{MATERIALS AND METHODS}

The stock colony of $T$. urticae was collected from maize plants grown in the Experimental Farm, Ismailia Agricultural Research Station, Egypt. The colony of $T$. urticae was kept on detached sweet potato branches (Ipomoea batatas [L.]), kept with their upper part of the stem in contact with water in glass vials at $27 \pm 1{ }^{\circ} \mathrm{C}$ and $60 \pm 10 \%$ R.H. Fresh and un-infested sweet potato branches were added once a week or when needed to keep the colony.

\section{Predator colony}

A colony of $B$. pallescens was established from nymphs and adults collected from maize plants (Zea mays) infested with T. urticae at the Experimental Farm, Ismailia Agricultural Research Station, Egypt. Adults and nymphs were maintained in plastic transparent jars (10 $\mathrm{cm}$ diameter $\times 20 \mathrm{~cm}$ height) covered with muslin held by rubber bands and kept under laboratory conditions of $27 \pm 1{ }^{\circ} \mathrm{C}$ and $60 \pm 10 \%$ R.H. Each jar was provided with sufficient quantities of $T$. urticae as a food supply and bean pods (Phaseolus vulgaris L.) as an ovipositional substrate (Isenhour and Yeargan, 1981). Bean pods with newly deposited eggs were removed and replaced daily. After hatching, B. pallescens nymphs were provided with $T$. urticae and small balls of foam to reduce cannibalism. Upon eclosion, adults were sexed and placed in new plastic jars, supplied with the TSSM as food and bean pods as ovipositional substrates (Sobhy et al. 2014).

\section{Experimental set up}

The four tested host plants for TSSM were bean ( $P$. vulgaris), pepper (C. annuum), eggplant ( $S$. melongena) and cucumber (C. sativus). TSSM nymphs were maintained on leaf discs of the tested host plants (3 $\mathrm{cm}$ diameter) and placed on water-soaked cotton in a Petri-dish $((9 \mathrm{~cm}$ diameter $\times 1.5 \mathrm{~cm}$ height $)$. To keep the leaves fresh, distilled water was daily added to cotton at regular basis. A colony of the TSSM was established on each of the tested host plant for at least three generations before conducting the intended experiments.

Effect of different host plants on prey consumption of $B$. pallescens nymphal stage

The effect of host plants on feeding consumption of nymphal stage of $B$. pallescens was determined at 30 $\pm 1{ }^{\circ} \mathrm{C}, 60 \pm 10 \%$ R.H for individuals fed on T. urticae nymphs. Fifteen replicates were used on each host plant.
In each replicate, a newly eclosed nymph (0-6 h old) was separated individually into a Petri dish $(9 \mathrm{~cm}$ diameter) using a small fine-hair brush. T. urticae nymphs were provided to the nymphs of $B$. pallescens on small leaf discs from the tested host plants. Each nymph was provided initially with $30 \mathrm{~T}$. urticae nymphs, this amount was increased by additional $20 \mathrm{~T}$. urticae nymphs after each molt. These increases in the amount of prey were based on preliminary tests to ensure that sufficient prey were available to the predator. Each Petri dish was inspected daily to determine the number of prey consumed. Predation was determined by visual examination of prey under a binocular microscope. T. urticae nymphs were provided on daily basis until $B$. pallescens nymphs completed their development to adulthood or died.

The mortality of $B$. pallescens during each nymphal instar and throughout the nymphal stage on the four host plants was recorded.

\section{Effect of host plants on prey consumption, longevity} and fecundity of $B$. pallescens adult stage

Prey consumption, longevity and fecundity of $B$. pallescens adults were evaluated on newly emerged females and males $(6 \mathrm{~h}$ old) that were separated on a plant leaf-disc with $T$. urticae nymphs. Females and males were paired in Petri dishes (9 $\mathrm{cm}$ diameter) and observed until mating occurred. Twelve hours later, males were removed and separated into other Petri dishes. Ten females or males were tested for each host plant. Each adult was supplied daily, with fifty $T$. urticae nymphs until death. The numbers of consumed prey longevity and fecundity were monitored daily until the death of all adults. The number of eggs deposited in the leaf-disc of each plant and the number of prey consumed by male and female adults were counted using a stereomicroscope. Experiments were conducted under the laboratory conditions of $\left(30 \pm 1{ }^{\circ} \mathrm{C}, 60 \pm 10 \%\right.$ R.H.

\section{Statistical analyses}

All experiments were subjected to analysis of variance (ANOVA) using CoStat 6311 Windows Computer Program. The data on prey consumption of nymphal stage as well as on prey consumption, fecundity and longevity of adult stages were analyzed by one-way ANOVA. Means were separated using Tukey's post-hoc comparison at 0.05 level of significance.

\section{RESULTS}

Effect of different host plants on prey consumption of $B$. pallescens nymphal stage

$B$. pallescens prey consumption was influenced by the type of host plant offered to its prey, T. urticae. The type of plant had a significant effect on the daily and total prey consumption of all the nymphal instars and total nymphal periods. The prey consumption increased as $B$. pallescens aged for which the mean daily and total predation rates of all nymphal instars were higher with bean plant (199.2 and 552.4 mites) than that of pepper (170.2 and 520.5mites), eggplant (125.6 and 451.8 mites) and cucumber (87.8 and 349.2 mites) respectively (Fig.1). 
B. pallescens nymphs were able to complete their development on TSSM fed on all tested plants but there were significant differences in nymphal mortalities when fed on TSSM reared on such host plants (Table 1). The major portion of the mortality during the nymphal stages of B. pallescens occurred during the first instar in all types of tested plants where the highest mortality recorded when fed on mites of cucumber plant and the lowest on mites reared on bean plant.
III Prey/instar

Prey/day
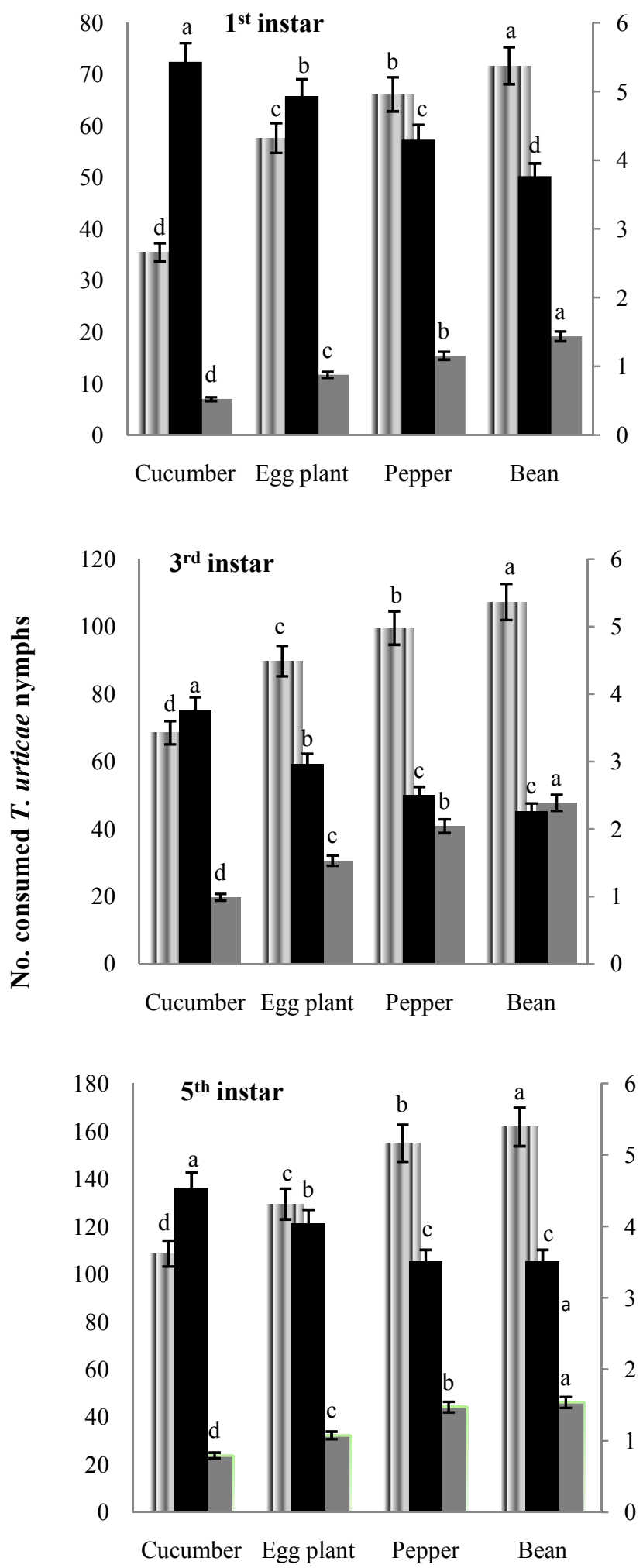

- Developmental time (days)
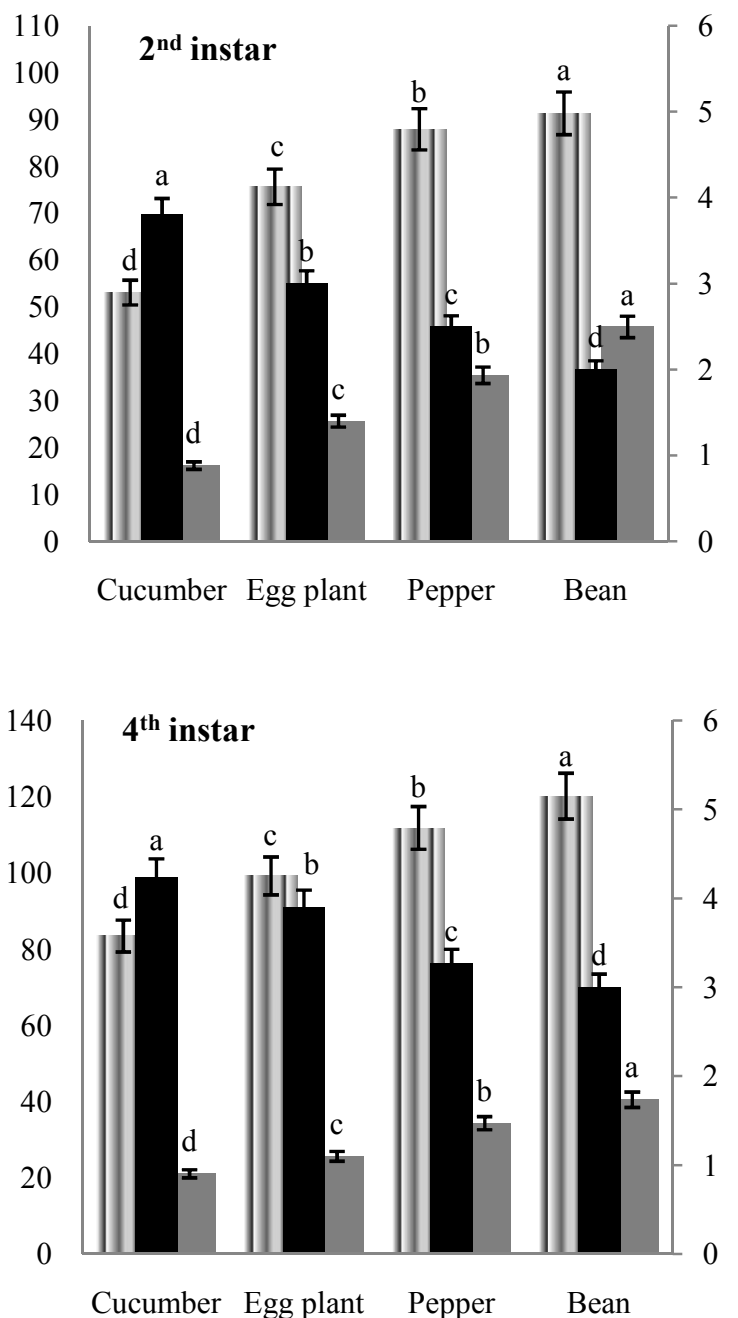

恣

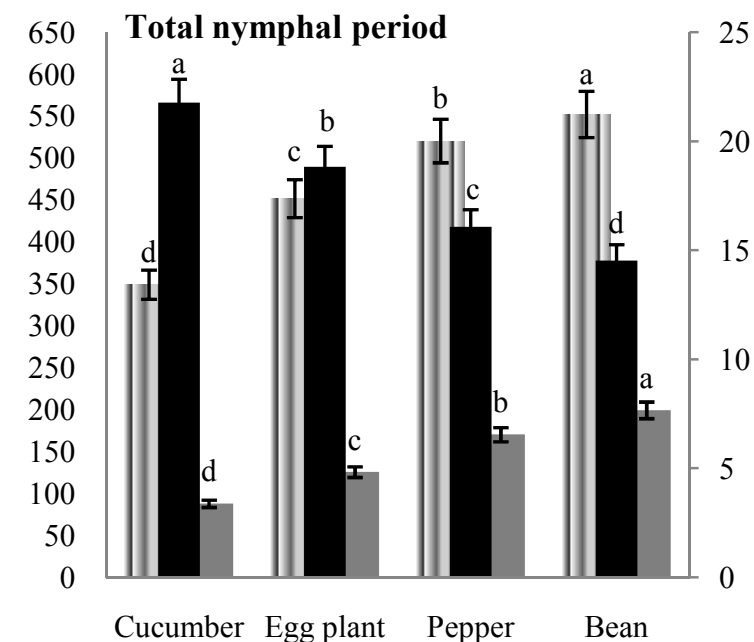

Fig. (1): Means $\left( \pm\right.$ SE) prey consumption of nymphal instars $\left(1^{\text {st }}, 2^{\text {nd }}, 3^{\text {rd }}, 4^{\text {th }}, 5^{\text {th }}\right.$ and total nymphal stage $)$ of $B$. pallescens fed on nymphal stage of T. urticae on four host plants under laboratory conditions of $30^{\circ} \mathrm{C}$ and $60 \%$ R.H. 
Table (1): Mortality of $B$. pallescens in each nymphal instar and throughout the nymphal stage fed on $T$. urticae nymphs on four host plants

\begin{tabular}{|c|c|c|c|c|c|c|c|c|c|c|c|c|}
\hline \multirow{2}{*}{ Nymphal instars } & \multicolumn{3}{|c|}{ Cucumber } & \multicolumn{3}{|c|}{ Eggplant } & \multicolumn{3}{|c|}{ Pepper } & \multicolumn{3}{|c|}{ Bean } \\
\hline & $\mathbf{n}_{\mathbf{x}}$ & $d_{x}$ & $\mathbf{q}_{\mathrm{x}}$ & $\mathbf{n}_{\mathbf{x}}$ & $d_{x}$ & $\mathbf{q}_{\mathrm{x}}$ & $\mathbf{n}_{\mathbf{x}}$ & $d_{x}$ & $\mathbf{q}_{\mathbf{x}}$ & $\mathbf{n}_{\mathbf{x}}$ & $d_{x}$ & $\mathbf{q}_{\mathbf{x}}$ \\
\hline $1^{\text {st }}$ & 50 & 20 & 40.0 & 50 & 14 & 28.0 & 50 & 7 & 14.0 & 50 & 5 & 10.0 \\
\hline $2^{\text {nd }}$ & 30 & 8 & 26.6 & 36 & 7 & 19.4 & 43 & 3 & 6.9 & 45 & 3 & 6.0 \\
\hline $3^{\text {rd }}$ & 22 & 4 & 18.1 & 29 & 4 & 13.7 & 40 & 2 & 5.0 & 42 & 2 & 4.7 \\
\hline $4^{\text {th }}$ & 18 & 2 & 11.1 & 25 & 2 & 8.0 & 38 & 1 & 2.6 & 40 & 1 & 2.5 \\
\hline $5^{\text {th }}$ & 16 & 1 & 6.2 & 23 & 1 & 4.3 & 37 & 0 & 0 & 39 & 0 & 0 \\
\hline $\begin{array}{l}\text { Total nymphal } \\
\text { instars }\end{array}$ & 50 & 35 & $70^{d}$ & 50 & 28 & $56^{c}$ & 50 & 13 & $26^{\mathrm{b}}$ & 50 & 11 & $22^{\mathrm{a}}$ \\
\hline
\end{tabular}

$\mathrm{n}_{\mathrm{x}}$ : number of individuals provided for the test.

$\mathrm{d}_{\mathrm{x}}$ : number of individuals that died during the nymphal stage.

$\mathrm{q}_{\mathrm{x}}$ : the mortality rate $\%$ during the nymphal stage.

Means followed with different letters in the same column are significantly different (Tukey' HSD; $\mathrm{P}<0.05$ )

Effect of host plant on prey consumption of $B$. pallescens adults

Host plant had a significant effect on prey consumption by $B$. pallescens adults. Female predators did consume significantly more preys than male predators. The total number of consumed $T$. urticae nymphs by $B$. pallescens adult females was significantly different among the four host plant; being higher in bean and pepper plants (301.9 and 296.1 mites, respectively) as compared to 221 mites in eggplant and 152.4 mites in cucumber plant (Table 2). The same trend was observed in adult males; the total number of consumed preys was $158.8,150.0,122.8$ and 105.3 mites in bean, pepper, eggplant and cucumber, respectively. Daily prey consumption did not differ significantly in case of bean and pepper plant while it differs significantly in eggplant and cucumber (Table 2).

Table (2): Mean $( \pm \mathrm{SE})$ daily and totally prey consumption of B. pallescens adults fed on T. urticae nymphs on four host plants at $30^{\circ} \mathrm{C}$ and $60 \%$ R.H.

\begin{tabular}{|c|c|c|c|c|}
\hline \multirow{2}{*}{ Host plants } & \multicolumn{2}{|c|}{ Daily no. of consumed preys } & \multicolumn{2}{|c|}{ Total no. of consumed preys } \\
\hline & Female & Male & Female & Male \\
\hline Cucumber & $9.20 \pm 0.1^{\mathrm{c}}$ & $7.8 \pm 0.8^{\mathrm{b}}$ & $152.4 \pm 4.1^{\mathrm{c}}$ & $105.3 \pm 4.9^{\mathrm{c}}$ \\
\hline Eggplant & $11.1 \pm 0.1^{\mathrm{b}}$ & $8.6 \pm 0.3^{\mathrm{ab}}$ & $221.0 \pm 8.6^{\mathrm{b}}$ & $122.8 \pm 2.8^{\mathrm{b}}$ \\
\hline Pepper & $13.5 \pm 0.3^{\mathrm{a}}$ & $8.8 \pm 0.2^{\mathrm{a}}$ & $296.1 \pm 8.6^{\mathrm{a}}$ & $150.0 \pm 3.6^{\mathrm{a}}$ \\
\hline Bean & $13.5 \pm 0.3^{\mathrm{a}}$ & $9.1 \pm 0.2^{\mathrm{a}}$ & $301.9 \pm 9.2^{\mathrm{a}}$ & $158.8 \pm 1.5^{\mathrm{a}}$ \\
\hline F value & 56.8 & 4.6 & 78.9 & 52.1 \\
\hline P value & 0.0000 & 0.0080 & 0.0000 & 0.0000 \\
\hline
\end{tabular}

Means followed with different letters in the same column are significantly different (Tukey' HSD; $\mathrm{P}<0.05$ ) 


\section{Effect of different host plants on longevity and fecundity}

As shown in (Table 3) significant differences in adult longevity among the different host plants were observed. The shortest lifetime for females (17.7 days) was for those fed on T. urticae on cucumber leaves, whereas there the longest one was on bean (22.3 days). The lifetime of adult males on bean, pepper eggplant and cucumber leaves were $(17.3,16.9,14.0$ and 12.9 days), respectively.

The longest pre-oviposition period was recorded on cucumber leaves (3.2 days). The duration of preoviposition period on pepper and eggplant was not significantly different (2.4 and 2.4 days), respectively. While, the shortest one was recorded on bean leaves (1.8 days). The post-oviposition periods were not significantly different on cucumber, eggplant and pepper (4.0, 3.6, 3.7 days), respectively, and the shortest one was recorded on bean leaves (2.8 days). The oviposition period was shortest on cucumber (10.5 days) but longest on bean (17.7days), while no significant differences existed on eggplant and pepper (13.8 and 15.4 days), respectively (Table 3 ).

Mean fecundity differed significantly among the four studied host plants (Table 3 ). The greatest means of total lifetime and daily fecundity were (70.0 and 3.9 eggs/female), respectively on bean leaves, decreased to 54.3 and 3.8 eggs/female, respectively on eggplant and to 48.0 and 3.0 eggs/female, respectively on pepper and 22.9 and 2.1 eggs/female respectively on cucumber leaves.

The percentage of eggs that hatched from the four host plants were affected by host plant; being greatest on bean leaf discs $(79.7 \%)$ and lowest on cucumber leaf discs $(58.7 \%)$ (Table 3).

Table (3): Mean ( \pm SE) ovipositional periods, longevity and fecundity of $B$. pallescens adults fed on $T$. urticae nymphs on four host plants at $30^{\circ} \mathrm{C}$ and $60 \%$ R.H.

\begin{tabular}{lcccccccc}
\hline \multirow{2}{*}{ Host plants } & \multicolumn{3}{c}{ Longevity (days) } & \multicolumn{2}{c}{$\begin{array}{c}\text { Total longevity } \\
\text { (days) }\end{array}$} & \multicolumn{2}{c}{ Fecundity (no. of eggs per female) } \\
\cline { 2 - 9 } & $\begin{array}{c}\text { Pre- } \\
\text { oviposition }\end{array}$ & Oviposition & $\begin{array}{c}\text { Post- } \\
\text { oviposition }\end{array}$ & Female & Male & Total & Per day Hatchability \\
Cucumber & $3.2 \pm 0.1^{\mathrm{c}}$ & $10.5 \pm 0.4^{\mathrm{c}}$ & $4.0 \pm 0.2^{\mathrm{a}}$ & $17.7 \pm 0.3^{\mathrm{c}}$ & $12.9 \pm 0.4^{\mathrm{b}}$ & $22.9 \pm 0.6^{\mathrm{d}}$ & $2.1 \pm 0.09^{\mathrm{c}}$ & $58.70^{\mathrm{d}}$ \\
\hline Egg plant & $2.4 \pm 0.1^{\mathrm{b}}$ & $13.8 \pm 0.6^{\mathrm{b}}$ & $3.7 \pm 0.1^{\mathrm{a}}$ & $19.8 \pm 0.6^{\mathrm{b}}$ & $14.0 \pm 0.3^{\mathrm{b}}$ & $54.3 \pm 2.6^{\mathrm{b}}$ & $3.87 \pm 0.1^{\mathrm{a}}$ & $70.75^{\mathrm{b}}$ \\
Pepper & $2.4 \pm 0.1^{\mathrm{b}}$ & $15.4 \pm 0.6^{\mathrm{b}}$ & $3.7 \pm 0.1^{\mathrm{a}}$ & $21.8 \pm 0.6^{\mathrm{a}}$ & $16.9 \pm 0.4^{\mathrm{a}}$ & $48.0 \pm 1.8^{\mathrm{c}}$ & $3.08 \pm 0.1^{\mathrm{b}}$ & $65.58^{\mathrm{c}}$ \\
Bean & $1.8 \pm 0.4^{\mathrm{a}}$ & $17.7 \pm 0.7^{\mathrm{a}}$ & $2.8 \pm 0.1^{\mathrm{b}}$ & $22.3 \pm 0.6^{\mathrm{a}}$ & $17.3 \pm 0.5^{\mathrm{a}}$ & $70.0 \pm 2.4^{\mathrm{a}}$ & $3.91 \pm 0.1^{\mathrm{a}}$ & $79.73^{\mathrm{a}}$ \\
\hline F value & 14.85 & 22.16 & 6.15 & 13.06 & 21.5 & 92.15 & 44.50 & 40.21 \\
P value & 0.0000 & 0.0000 & 0.0017 & 0.0000 & 0.0000 & 0.0000 & 0.0000 & 0.0000 \\
\hline
\end{tabular}

Means followed with different letters in the same column are significantly different (Tukey' HSD; $\mathrm{P}<0.05$ )

\section{DISCUSSION}

B. pallescens is a very important native predator in Egypt (Sobhy et al., 2014). The predation and oviposition rates of $B$. pallescens were monitored as two indices of the predator fitness on the host plants. In this study, the mean of prey consumption by nymphal and adults of $B$. pallescens varied among the four tested host plants (bean, pepper, eggplant and cucumber)that differ from each other by the morphology of their leaf surface.

The performance of $B$. pallescens as a predator of mites is influenced by the characteristics of the host plants. The type of plant had a significant effect on the daily and total prey consumption of all nymphal instars, total nymphal periods, female and male adults. The difference in trichome density on the four studied plants would affect $B$. pallescens movement ability, which can explain the differences in the data obtained in this experiment. So, the lowest consumption rate was found on cucumber and eggplant leaves that have heavy density of trichomes. Large stiff hairs on the leaf surface of cucumber and relatively few hairs in eggplant made a good shelter for the prey (T. urticae nymphs) to hide from the predator. However, higher consumption rates were found on bean and pepper plants that related to texture of their downy hairs in bean and no hairs with smoothness leaves in pepper. The presence of hairs on the leaves reduced the amount of time allocated to searching, interfered with the mobility of the mites and resulted in a reduced predation rate (Peterson, 1990). Several studies have shown that the physical characteristics of host plant may influence predator's performance (Price, 1980). Results of the current study are in harmony with those recorded by Peterson (1990), who mentioned that presence of hairs on cucumber leaves inhibited searching and reduced predation by Amblyseius cucumeris, and the search path of mites on pepper contained much more straight walk than on cucumber leaves. 
The longevity, oviposition periods, fecundity and mortalities of $B$. pallescens on the experimental plants showed the direct effect of host plant leaves structures. The difference in adult longevity of $B$. pallescens on the four host plants might be due to the differences in prey consumption and host plant. These results are in agreement with the conclusions reported earlier for $O$. laevigatus in different prey species and host plants (Zaki, 1989; Tommasini et al., 2004).

The leaf tissue has great effect on the oviposition rate of the predator which lays eggs inside the leaf tissue. Results showed that $B$. pallescens fecundity was higher on bean plants, followed by eggplant, while lower fecundity was observed for pepper and cucumber. Our results support the idea that some plants are unacceptable oviposition sites, especially in case of sweet pepper as thin thickness of the external covering may also render some species of plants unsuitable as oviposition sites (Castane and Zalom, 1994). Dense trichomes also as what have been seen in cucumber could render predators to find suitable place to penetrate their ovipositors (Armer et al., 1999; Roda et al., 2001). This conclusion is agreed with that reported earlier for the predatory thrips Scolothrips longicornis, which preferred lower densities of trichomes (Krips et al., 1999; Kheradpir et al., 2013).

The relation between the prey consumption ability of a predator and a plant is one of the important considerations in developing biological control strategies. The morphological feature of a plant affects the movement of a predator to such a degree that it is unable to move rapidly between patches of its prey. The success of $B$. pallescens as a biological control agent of TSSM seems to be strongly affected by the leaf surface characteristics of the host plants. Therefore, the superior ability of the predator to control mites on bean, may be attributed mainly to its higher predation rate and fecundity.

\section{REFERENCES}

Abd-Elhady, H. K and H. M. Heikal (2011). Selective toxicity of three acaricides to the two spotted spider mite Tetranychus urticae and predatory mite Phytoseuius persimilis in apple orchards. Journal of Entomology, 8: 574-580.

Abd-Elgayed, A. A and S. H. Hussein (2014). Host preference of the Anthocorid predator, Blaptostethus pallescens Poppius (Hemiptera: Anthocoridae) on certain Maize lepidopterous larva. Minufiya Journal of Agricultural Research, 39(6): 1927-1953.

Ahmed, M. F. (1988). Biological and ecological studies on family Tetranychidae. Ph.D. Thesis, Faculty of Agriculture, Cairo University, pp. 82.

Armer, C. A., R. N. Wiedenmann and M. E. Irwin (1999). Effects of soybean mosaic virus on the facultative phytophagous predator Orius insidiosus (Heteroptera: Anthocoridae). Environmental Entomology, 28: 1036-1043.

Ballal, C. R., T. Gupta, T., S. Joshi and K. Chandrashekhar (2009). Evaluation of an anthocorid predator, Blaptostethus pallescens against two-spotted spider mite, Tetranychus urticae. IOBC/wprs Bulletin, 49: 127-132.

Ballal, C. R, T. Gupta and S. Joshi (2012). Predatory potential of two indigenous anthocorid predators on Phenacoccus solenopsis and Paracoccus marginatus. Journal of Biological Control, 26: 18-22.

Castane, C. and F. G. Zalom (1994). Artificial oviposition substrate for rearing Orius insidiosus (Hemiptera: Anthocoridae). Journal of biological Control, 4: 88-91.

Eubanks, M. D. and R. F. Denno (2000). Health food versus fast food: the effects of prey quality and mobility on prey selection by a generalist predator and indirect interactions among prey species. Ecological Entomology, 25: 140-146.

Grevstad, F. S. and B. W. Klepetka (1992). The influence of plant architecture on the foraging efficiencies of a suite of ladybird beetle feeding on aphids. Oecologia, 92: 399-404.

Isenhour, D. J. and K. V. Yeargan (1981). Effect of temperature on the development of Orius insidiosus with notes on laboratory rearing. Annual Entomological Society of America, 74: 114-116.

Kheradpir, N., M. Rezapanah, K. Kamali and Y. Fathipour (2013). Host plant affects the predation and oviposition rate of the predaceous thrips of spider mites, Scolothrips longicornis. Munis Entomology and Zoology, 8 (1): 285-293.

Krips, O. E., P. W. Kelijn, P. E. Willems, G. J. Gols and M. Dicke (1999). Leaf hairs influence searching efficiency and predation rate of the predatory mite Phytoseiulus persimilis (Acari: Phytoseiidae). Experimental and Applied Acarology, 23: 119-131.

Lester, P. J., H. M. Thistlewood and R. Harmsen (2000). Some effects of pre-release host-plant on the biological control of Panonychus ulmi by the predatory mite Amblyseius fallacies. Experimental Applied of Acarology, 24: 19-33.

Price, P. W., C. E. Bouton, P. Gross, B. A. McPheron, J. N. Thompson and A. E. Weis (1980): Interactions among three trophic levels: influence of plants on interactions between insect hervivores and natural enemies. Annual review of ecological system, 11: 41-65.

Peterson, B. S. (1990). The effect of host plant on the biological control of Western flower thrips by the predatory mite, Amblyseius cucumeris.M.SC. Thesis, pp. 89.

Roda, A., J. Nyrop, G. English-Loeb and M. Dicke (2001). Leaf pubescence and two-spotted spider mite webbing influence phytoseiid behavior and population density. Oecologia, 129: 551-560.

Sarwari, M., W. Kongming, W. Xuenong and W. Endong (2011). Evaluations of four mite predators (Acari: Phytosiidae) released for suppression of spider mite infesting protected crop of sweet pepper (Capsicum annuum L.). African Journal of Agricultural Research, 6(15): 3509-3514. 
Singh, D., S. Kaur, T. Dhillon, P. Singh, J. Hundal and G. Singh (2004). Protected cultivation of sweet pepper hybrids under net-house in Indian conditions. Acta Horticulturae, 659: 515- 521.

Sobhy I, A. Abdul-Hamid, A. Sarhan, A. Shoukry, N. Mandour and S. Reitz (2014). Life history traits of Blaptostethus pallescens (Hemiptera: Anthocoridae), a candidate for use in augmentative biological control in Egypt. Applied Entomology of Zoology, 49: 315-324.

Tawfik, M. F. and M. M. El Husseini (1971). The lifehistory of the Anthocorid predator, Blaptostethus piceus Fieber var. pallescens Poppius (Hemiptera: Anthocoridae). Bulletin de la Societe Entomologique d'Egypte, 55: 239-252.

Tawfik, M. F., M. T. Kira and S. M. Metwally (1974). On the abundance of major pests and their associated predators in corn plantations. Bulletin de la Societe Entomologique d'Egypte, 58: 167177.

Tommasini, M. G., C. Joop, V. Lenteren and G. Burgio (2004). Biological traits and predation capacity of four Orius species on two Prey species. Bulletin of Insectology, 57(2): 78-79.

Zaher, M. A. (1986). Predaceous and non phytophagous mites in Egypt. Project No.EG-ARS-30, PI.480 Programme USA., RANT No. FG- EG-139.

Zaki, F. N. (1989). Rearing of two predators, Orius albidipennis (Reut.) and Orius laevigatus (Fieber) (Hem.: Anthocoridae) on some insect larvae. Journal of Applied Entomology, (107): 107-109.

Zhang, Z. (2003). Mites of greenhouses, identification, biology and control. Editoria CABI Pubishing, Cambridge, pp: 244.

\title{
تأثير أربعة عوائل نباتية لأكاروس العنكبوت الأحمر ذو البقتين Tetranychus urticae علي معدلات

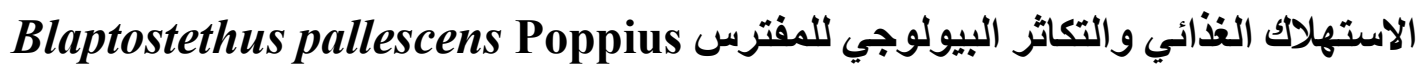

\author{
نسرين الباشات إنات \\ قسم بحوث المكافحة البيولوجية، معهُ بحوث وقاية النباتات، مركز البحوث الزراعية، الجيزة، مصر
}

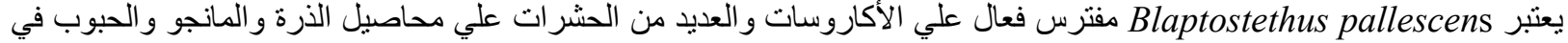

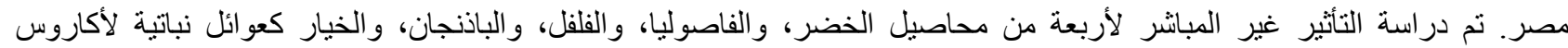

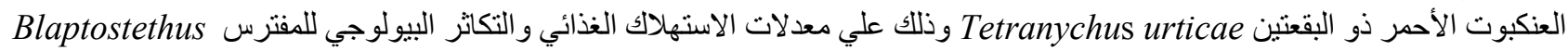
أعلي pallescens

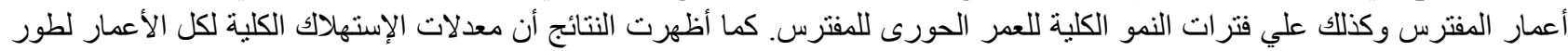

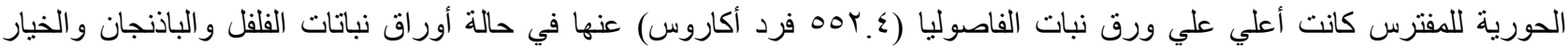

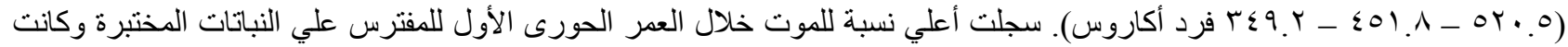

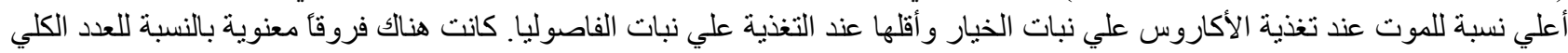
للأكاروس المستهلك بو اسطة إناث المفترس بين العو ائل النباتية الأربعة المختبرة وكان ألعان أعلاها (9.

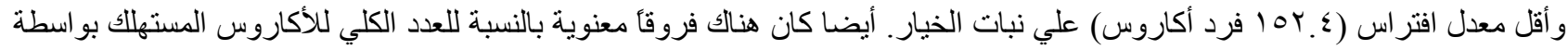

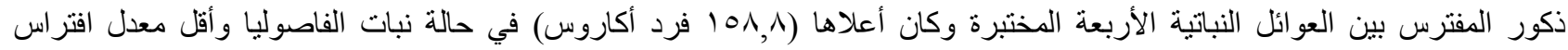

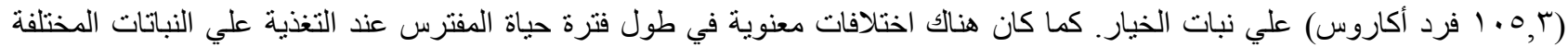

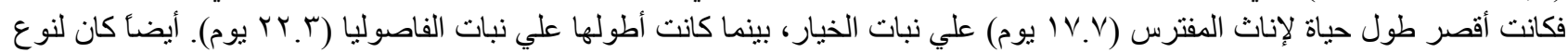

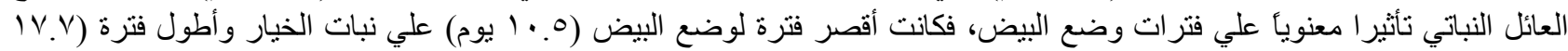

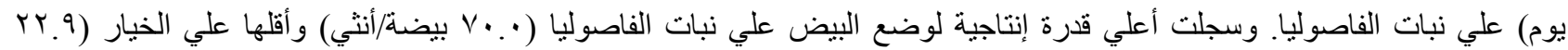

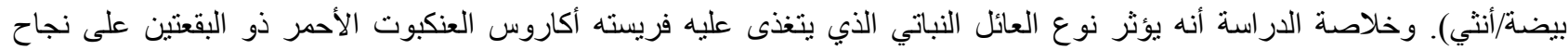

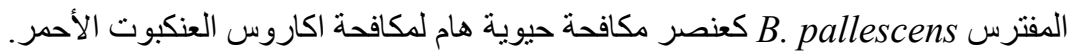

